\title{
Demand for money under low interest rates in Japan
}

\author{
Yutaka Kurihara $\mathrm{a}^{*}$ \\ a Professor, Department of Economics, Aichi University, Japan. \\ *Corresponding author's email address: kurihara@vega.aichi-u.ac.jp
}

\begin{abstract}
A R T I C LE I N F O
Received: 06-08-2016

Accepted: 20-08-2016

Available online: 26-08-2016

Keywords:

Demand for Money;

Exchange Rate;

Japan;

Monetary Policy;

Volatility.

JEL Classification:

A B S T R A C T

In both theoretical and empirical fields of economics, demand for money has been received much attention in the past. In Japan, deflation has been prevailed more than 20 years, and there is some possibility that the Bank of Japan's monetary easing policy, which expands money to markets by buying government bonds, has had a significant influence apart from traditional factors. Also, exchange rates for Japanese currency have fluctuated greatly recently because of the introduction of unprecedented monetary policy in the 2010s that may have affected macroeconomic variables and the money demand function in Japan. Using Japanese experience with deflation over last two decades, I provide strong evidence that recent demand for money is affected by real GDP, exchange rates, and economic volatility; however, interest rates and consumer prices have not impacted demand for money. The results also show that introduction of the drastic quantitative easing policy changed the demand function for money.
\end{abstract} E41, E43, E52.

(C) 2016 The Authors. This is an open access article under the terms of the Creative Commons Attribution License 4.0, which allows use, distribution and reproduction in any medium, provided the original work is properly cited.

DOI: http://dx.doi.org/10.18533/jefs.v4i04.247

\section{$1.0 \quad$ Introduction}

Demand for money has been discussed continuously and a great deal in the literature both in the theoretical and empirical fields of economics. In Japan, very low or almost zerio interest rate policies designed to overcome deflationary pressure have been in place since the end of 1990s after the bubble economy burst; also, exchange rates against the main foreign currencies and stock prices have fluctuated greatly, especially following the Lehman shock. The Japanese central bank, Bank of Japan (BOJ), bought a huge number of Japanese government bonds as part of its monetary policy, and there has been a strong demand for Japanese government bonds because of low interest rates and because of typical safe assets, so there is some possibility that the money demand function has changed dramatically such that it differs from the traditional money demand function.

The BOJ conducts monetary policy with the goal of maintaining price stability, which is thought to be important because it is considered to be the foundation of economic activity. This goal has been adopted in many countries and Japan is not an exception. However, deflation has seriously damaged the Japanese economy, so starting in 2013, more drastic monetary policy has been conducted and the BOJ set the price rate goal at $2 \%$. The main operating target of the BOJ's monetary policy changed from the uncollateralized overnight call rate (interbank interest rate) to the outstanding balance of the current account held at the BOJ as the interest rates in Japanese financial markets have been almost zero since the beginning of the 2000s.

At the end of 2001, the BOJ raised the outstanding balance of the current account at the BOJ. This objective can be perceived as a change from holding a level of reserves at the $\mathrm{BOJ}$ to one that transfers funds into lending to boost 
the economy and remove deflationary pressures. Under this quantitative easing policy, the BOJ purchased Japanese government bonds to reach its target of current account balances held by financial institutions such as banks. With interest rates were at the lower bound of zero, the BOJ set a goal to purchase government bonds from financial institutions and to raise the level of cash reserves held by private financial institutions. With interest rates at the zero bound, the BOJ lost conventional instruments to stimulate the real economy. This was called unconventional financial policy, which was unprecedented in the world at that time. However, only a few studies have examined this policy despite that such examinations are very important. One serious reason for the lack of studies is that only a short time has passed since this unprecedented policy was implemented.

On April 4, 2013, the policy board of the BOJ decided to introduce quantitative and qualitative monetary easing policy, a more aggressive monetary policy. The BOJ decided to attain the price target of $2 \%$ in terms of the yearon-year rate of change in consumer prices. It was said that the BOJ imposed a new phase of monetary easing both in terms of quantity and quality. The BOJ doubled the monetary base and the amounts outstanding of Japanese government bonds as well as exchange-traded funds (ETFs) in two years and more than doubled the maturity of Japanese government bond purchases (quality). To achieve quantitative monetary easing, the main target of financial policy instruments was changed from the uncollateralized overnight call (interbank interest) rate to the monetary base as mentioned above.

Anusic (1994) showed that the main determinants of the demand for money are inflation and real economic activity, and interest rates have no impact on money demand in Croatia. Arize (1994) used ECM (error-correction model) and found that Taiwanese demand for money is stable and that interest rates of foreign countries play important roles in determining demand for money. Klacek and Smidkova (1995) showed the expected signs for inflation and interest rates. Bahmani-Oskooee and Bohl (2000) showed that cointegration does not necessarily imply a stable relationship between the variables for Germany. Choi and Oh (2003) showed that economic uncertainty can affect the public's decisions in allocating their wealth among different financial assets. The authors found that output uncertainty had negative effect on money demand and monetary uncertainty had positive effect on demand in the United States. Bahmani-Oskooee and Rehman (2005) showed that in some Asian countries, real M1 and M2 money aggregates are cointegrated and the estimated variables are unstable. Rao and Singh (2005) showed that money demand of M1 has been stable. Hussain (2007) indicated that long-run income elasticity of the demand for narrow money has remained stable. Zouhar and Kacemi (2008) showed that there is a strong link between real narrow money, real GDP, and interest rate. Odularu and Okunrinboye (2009) found that income is positively related to money demand but financial innovation has not affected the money demand in Nigeria. Rao and Kumar (2011) showed that US demand for money has been stable. Singh and Kumar (2010) found that real income, nominal interest rate, and narrow money are cointegrated and demand for money is stable. Avouyi-Dovi, Drumetz, and Sahuc (2012) showed that money demand function is unstable for the Euro area by using vector error correction model.

Dobnik (2013) examined the long-run money demand function for OECD countries and found that impact of income on money demand is positive but negative for interest rate, exchange rate, and stock prices. Dogru and Recepoglu (2013) found that real demand for money in Turkey is positively related to income and negatively related to nominal interest rate. Khan and Hye (2013) demonstrated that GDP and real deposit rates positively impact the demand for money both in long- and short-run periods. Kumar, Chowdhury, and Rao (2013) showed that income elasticity of the demand for money has increased and response to interest rate changes has increased. Paudel and Perera (2013) indicated that liberalization does not have a positive relationship with money demand. Sarwar, Sarwar, and Waqas (2013) showed that demand for money using M1 has been stable, real GDP is positively related, and opportunity cost of money is negatively related. Jiranyakul and Opiela (2014) found that in the short term, only a change in real GDP affects M1 money holdings. Also, in the long term, both real GDP and interest rate determine money demand. As many developed countries are under deflationary pressures and people hold money instead of investing risky assets, demand for money, which has been very traditional in the field of economics, should receive a lot of attention. It is difficult to conclude, however, as most studies confirm the traditional theory for money demand, which includes income and interest rate as explanation variables, although there are exceptions for various time periods, countries, and so on.

Exchange rates have not received attention in the past in analysis of demand for money. Arango and Nadiri (1981) showed that exchange rate depreciation has a positive impact on the demand for money as the domestic currency value of foreign assets, which leads to an increase in the wealth of the country and an increase in the demand for real cash balances. Craig (1982) found that the exchange rate in West Germany relates to demand for money. Bamani-Oskooee and Pourheydarian (1990) showed that when domestic currency depreciates, this can most certainly cause markets. Bahmani-Oskooee and Malixi (1991) found that depreciation of domestic currency promotes a decrease in the demand for domestic currency in many less developed countries. Bahmani-Oskooee, Miquel-Angel, and Niroomand (1998) demonstrated that demand for money, including the effective exchange rate, 
were stable. Hueng (1998) showed that changes in the foreign interest rate and exchange rate affect the demand for money in Canada. Cuthbertson and Bredin (2001) indicated the degree of dollarization of the economy impacts the demand for money. Gunnar (2001) argued that shocks to the nominal exchange rate impact domestic prices in the short term but have no impact on real output, and shocks to money have a temporary impact on real output before causing inflation. Klos and Wrobel (2001) showed significant effects of exchange rate changes on demand for money. Dreger, Hans-Eggert, and Roffia (2007) showed that for new EU member states, the US exchange rate is significantly related to demand for money. Tang (2007) demonstrated that the real M2 aggregate, real expenditure components, exchange rate, and inflation have a cointegration relationship in Malaysia, Philippines, and Singapore. Yu (2008) showed that the demand for real M1 in Argentina had a positive relationship with real income and peso depreciation in Argentina. Abdullah, Ali, and Matahir (2010) found that depreciation of domestic currency increases the demand for money. Arize and Nam (2012) showed that increases in the exchange rate have a significant and positive effect on money demand and that exchange rate and domestic interest rates have positive and negative impacts respectively on money demand.

Abdulkheir (2013) showed the existence of a long-run cointegration relationship between the demand for money and its explanatory variables (i.e., real GDP, interest rate, inflation rate, and exchange rate). Moreover, along with the changing of economic circumstances, demand for money, which is not necessarily a new topic of economics, has been discussed and examined again recently. Bahmani (2013) showed that exchange rate volatility has shortrun effects on the demand for real M2 monetary aggregate in less developed countries; on the other hand, these short-run effects are not sustained. Hussain and Wijeweera (2013) showed that real GDP has a positive impact on the demand for real money and interest rate and exchange rate have a negative impact on money demand for M1. Kjosevski (2013) found that exchange rate and interest rate payable on time deposits up to one month explains the most variations of money demand in the long term, and interest rate is significant only in the short term. It is also difficult to conclude, depending on kinds of exchange rates, time, and so on, but the effects of exchange rates on demand for money is inconclusive.

This paper examines the recent Japanese demand for money function. Demand for money, including the Japanese case, has been discussed a lot; however, exchange rates have not been considered in the empirical analyses in many cases. Also, the recent Japanese economic and financial condition (i.e., drastic monetary policy and almost zero interest rate) may have greatly changed the demand function for money. This situation has not been considered, though it seems very important not only for the business world but also for policymakers. When deciding economic policies, demand for money has and should be examined and considered.

This paper is structured as follows. Section 2 provides theoretical background for the empirical analysis. Section 3 shows the empirical analyses. Section 4 reviews the results and ends with a brief summary.

\subsection{Theory and hypothesis development}

This study examines basically traditional demand for money function in Japan; however, (1) exchange rate and (2) economic uncertainty are considered in the estimations. Few studies have examined the impact of economic uncertainty on the demand for money, including Japanese case. Along with the traditional variables, two nontraditional variables (i.e., exchange rate and economic volatility) are included in the empirical equation, as there seems some possibility that demand for money has changed significantly. This paper examines this equation. Since the 2000s, world economic activity has changed and fluctuated to a large degree. The estimation equation is as shown in (1).

$\ln M_{t}=\alpha+\beta_{1}\left(\operatorname{lnRGDP} P_{t}\right)+\beta_{2}\left(\operatorname{lNTEREST}_{\mathrm{t}}\right)+\beta_{3}\left(\ln \left(\mathrm{P}_{\mathrm{t}} / \mathrm{P}_{\mathrm{t}-1}\right)\right)+\beta_{4}(\operatorname{lnEXC} \mathrm{t})+\beta_{5}\left(\operatorname{lnVOLATILITY}_{\mathrm{t}}\right)+\varepsilon_{\mathrm{t}}$

where $\mathrm{t}$ means time. M denotes real M1 and real M2 (both are seasonally adjusted real ones). A measure of economic activity is real income (RGDP), which indicates transaction demand for money. $\beta_{1}$ is an estimate of income elastic and is expected to be positive. The measure of opportunity cost of holding money against financial assets is interest rate (INTEREST). $\beta_{2}$ should be negative. Interest rates seem to be no longer available as a stimulating instrument; however, the usefulness of money as a policy instrument is still conditional. As an interest rate, money market interest rate is used for estimations. The inflation rate [i.e., ln (Pt/Pt-1)] measures the opportunity cost against real assets. $\beta_{3}$, is expected to be negative. For the inflation rate, consumer price is used. To explain the degree of each currency substitution between domestic and foreign currency, the exchange rate, EXC, is included in the regression analysis. This variable has been regarded as unimportant or an ineffective variable against money supply. The exchange rate is the effective exchange rate. Hence, a decline reflects depreciation. Because the depreciation of domestic currency promotes domestic currency value of foreign assets held by domestic residents, the demand for money could rise as a result of perceived increase in wealth (Arango and Nadiri, 1981). However, Bahmani-Oskooee and Pourheydarian (1990) demonstrated that if depreciation of 
domestic currency causes increased expectations for more depreciation, domestic residents have less domestic currency and more foreign currency. Therefore, an estimate of $\beta_{4}$ could be negative or positive. It would be inconclusive. The measure of economic volatility (i.e., real output volatility) is also estimated. Increased volatility of economic uncertainty makes market participants more pessimistic, and they save money by increasing cash holdings. However, the strong degree of substitution between money and other less volatile assets, such as Japanese government bonds, could have negative effects on the demand for money. So the coefficient of $\beta_{5}$ is inconclusive.

\subsection{Empirical analysis}

\subsection{Method}

The sample period is from 1990Q1 to the latest 2015Q4. The sample period is divided into two; from 1990Q1 to 2001Q4 and from 2002Q1 to 2015Q4. At the end of 2001, the BOJ raised the outstanding balance of the current account at the BOJ at the beginning of unprecedented financial policy. This policy has been changing gradually and sometimes drastically; however, the basic stance to boost the economy has not been changing. From 2006 to 2012 , quantitative easing policy was not performed; in April 2013, a drastic monetary easing policy was implemented and has continued since then. However, the stance is not different (scale and contents are different), so the sample period is set like this. One reason is the number of samples. All of the data are from International Financial Statistics (IMF).

\subsection{Regression analyses}

Empirical methods are OLS (ordinary least squares), GMM (generalized method of moments). One problem in equations that use the OLS method is the existence of unobservable specific effects and also lagged dependent variables. This problem can be overcome with the use of the GMM. GMM requires a decision on which variables to use as instrumental variables. J-test is used for estimation. This test checks whether or not the model's moment contains match the data. In a GMM context, when there are more moment conditions than parameters to be estimated, this chi-square test can be used to test the over-identifying restrictions. In this analysis, the lagged values of the dependent variables are used as instrumental variables.

\begin{tabular}{lrrr}
\hline \multicolumn{4}{c}{ Table 1: Demand for money (M1) in Japan } \\
\hline 1990Q1-2015Q4 & 1990Q1-2001Q4 & 2002Q1-2015Q4 \\
\hline C & $-2.157^{* * *}$ & $7.668^{* * *}$ & $8.390^{* * *}$ \\
RGDP & $(-3.971)$ & $(5.140)$ & $(10.212)$ \\
& $8.012^{* * *}$ & $3.358^{* * *}$ & $2.724^{* * *}$ \\
INTEREST & $(30.120)$ & $(4.513)$ & $(6.654)$ \\
& $-0.046^{* * *}$ & $-0.091^{* * *}$ & -0.003 \\
PRICE & $(-7.021)$ & $(-9.040)$ & $(-0.629)$ \\
& 0.019 & 0.012 & 0.011 \\
EXCHANGE & $(1.021)$ & $(0.620)$ & $(1.014)$ \\
& $0.402^{* * *}$ & -0.008 & $0.151^{* *}$ \\
VOLATILITY & $(3.307)$ & $(-0.058)$ & $(2.063)$ \\
& -4.461 & 1.623 & $12.995^{* * *}$ \\
Adj.R2 & $(-1.062)$ & $(0.441)$ & $(3.877)$ \\
F-statistic (Prob) & 0.934 & 0.921 & 0.698 \\
& 291.447 & 101.487 & 23.702 \\
Durbin-Watson & $(0.000)$ & $(0.000)$ & $(0.000)$ \\
Note. Figures in parentheses are t-statistic. $* * *, * *$ & and ${ }^{*}$ denote significance at $1,5,10 \%$. \\
\end{tabular}

Almost all of the results are clear and some of them are as expected. The coefficients of interest rates are negative as expected for the first half; however, they are not significant for the latter part. The reason is the low or zero interest rates policies enacted in the 2000s. Interest rates have become insensitive by now. Prices also are insensitive; however, they are insensitive for all of the periods. The reason is similar to the case of interest rates and they are quite low (i.e., deflation). The results of exchange rates may explain that the depreciation of domestic currency (plus means depreciation of the yen) promotes domestic currency value of foreign assets held by 
domestic people, so the demand for money could rise as a result of perceived increase in wealth; however, it is insignificant for the first estimation period. Finally, volatility of economic activity increased for the latter sample period. During the 2000s, large economic shocks occurred and was a huge demand for money for safe assets.

\begin{tabular}{lrrrr}
\hline \multicolumn{5}{c}{ Table 2: Demand for money (M2) in Japan } \\
\hline & \multicolumn{5}{c}{ OLS } & GMM \\
\hline C & $9.423^{* * *}$ & $12.477^{* * *}$ & $11.387^{* * *}$ & $10.935^{* * *}$ \\
& $(46.323)$ & $(24.660)$ & $(20.428)$ & $(16.198)$ \\
RGDP & $2.513^{* * *}$ & $1.123^{* * *}$ & $1.500^{* * *}$ & $1.772^{* * *}$ \\
& $(25.234)$ & $(4.452)$ & $(4.864)$ & $(5.096)$ \\
INTEREST & $-0.006^{* * *}$ & $-0.028^{* * *}$ & -0.0006 & -0.0003 \\
& $(-2.811)$ & $(-8.209)$ & $(-0.108)$ & $(-0.068)$ \\
PRICE & $0.013^{*}$ & 0.006 & 0.007 & 0.006 \\
& $(1.954)$ & $(0.852)$ & $(0.726)$ & $(0.476)$ \\
EXCHANGE & $0.213^{* * *}$ & 0.035 & $0.198^{* * *}$ & $0.192^{* *}$ \\
& $(4.691)$ & $(0.746)$ & $(2.982)$ & $(2.408)$ \\
VOLATILITY & $4.034^{* *}$ & 1.307 & $14.127^{* * *}$ & $12.718^{* * *}$ \\
& $(2.563)$ & $(1.047)$ & $(4.044)$ & $(3.876)$ \\
Adj.R2 & 0.913 & 0.915 & 0.936 & 0.706 \\
F-statistic (Prob) & 196.847 & 93.748 & 120.292 & \\
& $(0.000)$ & $(0.000)$ & $(0.000)$ & \\
J-statistic(Prob) & & & \\
Durbin-Watson & 0.502 & 0.747 & 0.955 & $4.07 \mathrm{E}-37$ \\
\hline Note. Figures in parentheses are t-statistics. ${ }^{* * *}, * *$ & and $*$ denote significance at $1,5,10 \%$. \\
\hline
\end{tabular}

Moreover, the time lag of explanation variables influences the effects of money demand. M2 is regressed by each lagged variable. The results are shown in Table 3.

\begin{tabular}{lrrrr}
\hline \multicolumn{5}{c}{ Table 3: Effects of lagged variables on the demand for money (M2) in Japan } \\
\hline One-Time Lag & Two-Time Lag & Three-Time Lag & Four-Time Lag \\
\hline C & $9.461^{* * *}$ & $9.496^{* * *}$ & $9.526^{* * *}$ & $9.538^{* * *}$ \\
RGDP & $(47.973)$ & $(49.748)$ & $(50.577)$ & $(52.198)$ \\
& $2.472^{* * *}$ & $2.433^{* * *}$ & $2.406^{* * *}$ & $2.382^{* * *}$ \\
INTEREST & $(25.362)$ & $(25.553)$ & $(-2.897)$ & $(25.778)$ \\
& $-0.007^{* * *}$ & $-0.007^{* * *}$ & $-0.007^{* * *}$ & $-0.006^{* * *}$ \\
PRICE & $(-2.958)$ & $(-2.995)$ & $(-2.897)$ & $(-2.714)$ \\
& $0.019^{* * *}$ & $0.022^{* * *}$ & $0.021^{* *}$ & $0.019^{* * *}$ \\
EXCHANGE & $(2.749)$ & $(3.209)$ & $(3.068)$ & $(2.883)$ \\
& $0.238^{* * *}$ & $0.262^{* * *}$ & $0.276^{* * *}$ & $0.295^{* * *}$ \\
VOLATILITY & $(5.338)$ & $(6.030)$ & $(6.457)$ & $(7.082)$ \\
& $3.887^{* *}$ & $3.666^{* *}$ & $3.717^{* *}$ & $3.122^{* *}$ \\
Adj.R2 & $(2.535)$ & $(2.462)$ & $(2.547)$ & $(2.164)$ \\
F-statistic (Prob) & 0.918 & 0.922 & 0.923 & 0.923 \\
& 205.980 & 215.919 & 217.903 & 225.817 \\
Durbin-Watson & $(0.000)$ & $(0.000)$ & $(0.000)$ & $(0.000)$ \\
\hline Note. Figures in parentheses are t-statistics. ${ }^{* * *}, * *$ & 0.489 & 0.499 & 0.493 \\
\hline
\end{tabular}

The results are conclusive; however, the results should be also analyzed with those shown in Tables 1 and 2 .

\subsection{Causality test}

Granger causality tests also were performed to check the relationship among the explanation variable and dependent variable. This test is as follows: A time series $X$ is said to Granger-cause $Y$ if one can show a series of $\mathrm{t}$ 
value and $\mathrm{F}$ value on lagged values of $X$ (lagged values of $Y$ included) and those $X$ values give statistically significant for values of $Y$. The estimations of the equation. The results are Table 4.

Table 4: Pairwise Granger causality tests

\begin{tabular}{lrr} 
Null Hypothesis & F-Statistic & Prob. \\
\hline GDP does not Granger Cause M2 & 5.794 & 0.018 \\
M2 does not Granger Cause GDP & 1.942 & 0.167 \\
INTEREST does not Granger Cause M2 & 4.542 & 0.036 \\
M2 does not Granger Cause INTEREST & 0.024 & 0.879 \\
PRICE does not Granger Cause M2 & 0.372 & 0.544 \\
M2 does not Granger Cause PRICE & 0.033 & 0.857 \\
EXCHANGE does not Granger Cause M2 & 3.718 & 0.057 \\
M2 does not Granger Cause EXCHANGE & 0.229 & 0.634 \\
VOLATILITY does not Granger Cause M2 & 27.228 & $1.00 \mathrm{E}-06$ \\
M2 does not Granger Cause VOLATILITY & 0.521 & 0.472
\end{tabular}

The results are almost expected. It can be said safely that demand function of this study is quite stable.

\subsection{Conclusions}

In Japan, low or almost zero interest rates has prevailed, and there has been a strong demand for Japanese government bonds, so there is some possibility that money demand has changed dramatically. The findings are important to consider in deciding on economic policies. This paper examined the recent Japanese case. Despite recent dramatic changes in the economy, money demand function is very stable and accountable mostly according to the traditional money demand function presented by traditional economic theory. Empirical evidence shows that demand for money has recently been affected by real GDP, exchange rates, and economic uncertainty. It may be said that market participants can have faith in the policies because demand for money is stable and predictable. However, the effects of interest rates on demand for money disappeared recently, which can be expected as a result of low or zero interest rate policies. Also, the empirical results show that exchange rate has developed an influence on money demand. Because depreciation of domestic currency promotes domestic currency value of foreign assets held by domestic residents, the demand for money could rise as a result of a perceived increase in national wealth. Moreover, the results show that introduction of the drastic quantitative easing policy changed the demand function for money.

Finally, the Japanese government not only implemented drastic economic policy but also took measures to strengthen competitiveness and economic growth. These measures included possible policy actions to reform the economic structure, such as concentrating resources on innovative research and development, strengthening the foundation for innovation, performing regulatory and institutional reforms, and changing the tax system. Moreover, by strengthening coordination between the BOJ and the government, the Japanese government has implemented measures to achieve a new fiscal structure to ensure the credibility of the fiscal condition since 2013. This approach is called Abenomics. Abe is from the name of Japan's current prime minister. So much more time to do research seems necessary as there is some possibility that demand for money function may change.

Acknowledgements: I appreciate the editor and the referee for their valuable comments and suggestions. I was supported by JSPS KAKENHI Grant Number $15 \mathrm{H} 03366$ for this work.

\section{References}

Abdullah, H., Ali, J., \& Matahir, H. (2010). Re-examining the demand for money in Asean-5 countries. Asian Social Science, 6(7), 146-155. http://dx.doi.org/10.5539/ass.v6n7p146

Abdulkheir, A. Y. (2013). An analytical study of the demand for money in Saudi Arabia. International Journal of Economics and Finance, 5(4), 31-38. http://dx.doi.org/10.5539/ijef.v5n4p31

Anusic, Z. (1994). The determinants of money demand in Croatia and simulation of the post-stabilization period. Croatian Economic Survey, 2, 85-120.

Arize, A. C. (1994). An econometric analysis of money demand in Taiwan, 1950-1989. American Economist, 38(1), 27-35. http://dx.doi.org/10.1177/056943459403800104

Arize, A., \& Nam, K. (2012). The demand for money in Asia: some further evidence. International Journal of Economics and Finance, 4(8), 59-71. http://dx.doi.org/10.5539/ijef.v4n8p59

Avouyi-Dovi, S., Drumetz, F., \& Sahuc, J. G. (2012). The money demand function for the Euro area: Some empirical 
evidence. Bulletin of Economic Research, 64(3), 377-392. http://dx.doi.org/10.1111/j.14678586.2010.00388.x

Bahmani, S. (2013). Exchange rate volatility and demand for money in less developed countries. Journal of Economics and Finance, 37(3), 442-452. http://dx.doi.org/10.1007/s12197-011-9190-y

Bahnami-Oskooee, M. \&, Bohl, M. T. (2000). German monetary unification and the stability of the German M3 money demand function. Economics letters, 66(2), 203-208. http://dx.doi.org/10.1016/S01651765(99)00223-2

Bahmani-Oskooee, M., \& Malixi, M. (1991). Exchange rate sensitivity of the demand for money in developing countries. Applied Economics, 23(8), 1377-1384. http://dx.doi.org/10.1080/00036849100000060

Bahmani-Oskooee, M., Miquel-Angel, M., \& Niroeemand, F. (1998). Exchange rate sensitivity of the demand for money in Spain. Applied Economics, 30(5), 607-612. http://dx.doi.org/10.1080/000368498325598

Bahmani-Oskooee, M., \& Pourheydarian, M. (1990). Exchange rate sensitivity of the demand for money and effectiveness of fiscal and monetary policies. Applied Economics, 22, 1377-1384. http://dx.doi.org/10.1080/00036849000000029

Bahnami-Oskooee, M., \& Rehman, H. (2005). Stability of money demand function in Asian developing countries. Applied Economics, 37(7), 773-792. http://dx.doi.org/10.1080/0003684042000337424

Choi, W. G., \& Oh, S. (2003). A demand function with output uncertainty, monetary uncertainty, and financial innovations. Journal of Money, Credit, and Banking, 35(5), 685-709. http://dx.doi.org/10.1353/mcb.2003.0034

Craig, H. (1982). Exchange rate determination and the demand for money. The Review of Economics and Statistics, 64(4), 681-686. http://dx.doi.org/10.2307/1923952

Cuthbertson, K., \& Bredin, D. (2001). Money demand in the Czech Republic since transaction. Journal of Policy Reform, 4(4), 271-290. http://dx.doi.org/10.1080/13841280108523422

Dobnik, F. (2013). Long-run money demand in OECD countries: What role do common factors play? Empirical Economics, 45(1), 89-113. http://dx.doi.org/10.1007/s00181-012-0600-6

Dogru, B., \& Recepoglu, M. (2013). Dynamic analysis of money demand function in Turkey. International Journal of Economics and Finance, 5(9), 20-27. http://dx.doi.org/10.5539/ijef.v5n9p20

Dreger, C., R. Hans-Eggert, R., \& Roffia, B. (2007). Long-run money demand in the new EU member states with exchange rate effects. Eastern European Economics, 45(2), 75-94. http://dx.doi.org/10.2753/EEE00128775450204

Gunnar, J. (2001). Inflation, money demand, and purchasing power parity in South Africa. IMF Staff Papers, 48(2), 243-265.

Hueng, C. J. (1998). The demand for money in an open economy: Some evidence for Canada. North American Journal of Economics and Finance, 9(1), 15-31. http://dx.doi.org/10.1016/S1062-9408(99)80078-3

Hussain, A. A. (2007). The narrow money demand behavior in Indonesia, 1970-2005. ASEAN Economic Bulletin, 24(3), 320-338. http://dx.doi.org/10.1355/AE24-3C

Hussain, M. N., \& Wijeweera, A. (2013). Estimation of the money demand function in a heterogeneous panel for selected Asian countries. Indian Journal of Economics and Business, 12(1), 23-35.

Jiranyakul, K., \& Opiela, T. P. (2014). Instability of money demand: Recent evidence for Thailand. Modern Economy, 5(8), 907-913. http://dx.doi.org/10.4236/me.2014.58083

Khan, R. E. A., \& Hve, Q. M. A. (2013). Financial liberalization and demand for money: A case of Pakistan. The Journal of Developing Areas, 47(2), 175-198. http://dx.doi.org/10.1353/jda.2013.0034

Kjosevski, J. (2013). The determinants and stability of money demand in the Republic of Macedonia. Journal of Economics and Business, 31(1), 35-54.

Klacek, J., \& Smidkova, K. (1995). The demand for money function: The case of the Czech economy. Working Paper Series 41, Czech National Bank Praha.

Klos, B., \& Wrobel, E. (2011). The monetary transmission mechanism and the structural modelling of inflation at the National Bank of Poland. National Bank of Poland.

Kumar, S., Chowdhury, M. B., \& Rao, B. B. (2013). Demand for money in the selected OECD countries: A time series panel data approach and structural breaks. Applied Economics, 45, 13-15. http://dx.doi.org/10.1080/00036846.2011.637897

Odularu, G. O., \& Okunrinboye, O. A. (2009). Modeling the impact of financial innovation on the demand for money in Nigeria. African Journal of Business Management, 3(2), 39-51.

Paudel, R. C., \& Perera, N. (2013). Does financial liberalisation boost money demand? Evidence from Sri Lanka. Indian Journal of Economics and Business, 12(2-4), 223-242.

Rao, B., \& Singh, R. (2005). Cointegration and error correction approach to the demand for money in Fiji. Pacific Economic Bulletin, 20(2), 76-82.

Rao, B. B., \& Kumar, S. (2011). Is the US demand for money unstable? Applied Financial Economics, 21, 1263-1272. http://dx.doi.org/10.1080/09603107.2011.568395

Sarwar, H., Sarwar, M., \& Waqas, M. (2013). Stability of money demand function in Pakistan. Economic and Business Review, 15(3), 197-212. 
Singh, R., \& Kumar, S. (2010). Some empirical evidence on the demand for money in the Pacific island countries. Studies in Economics and Finance, 27(3), 211-222. http://dx.doi.org/10.1108/10867371011060045

Tang, T. C. (2007). Money demand function for Southeast Asian countries: An empirical view from expenditure components. Journal of Economic Studies, 34(6), 476-496. http://dx.doi.org/10.1108/014435807108309 52

$\mathrm{Yu}, \mathrm{H}$. (2008). Impacts of the exchange rate and the foreign interest rate on the Argentine money demand function. Applied Economics Letters, 15(1), 35-39. http://dx.doi.org/10.1080/13504850600706685

Zouhar, Y., \& Kacemi, A. (2008). Financial liberalisation and money demand in Morocco. Working Paper, 389, Economic Research Forum. 